PRINT ISSN 1119-8362

Electronic ISSN 1119-8362
Full-text Available Online at https://www.ajol.info/index.php/jasem http://ww.bioline.org.br/ja
J. Appl. Sci. Environ. Manage.

Vol. 24 (12) 2061-2064 December 2020

\title{
Evaluation of Changes in Food Properties and Mineral Composition of Tiger Nuts at Variable Drying Temperatures
}

\author{
*AKHIHIERO, ET; EBHODAGHE, SO; AGBAHOWE, SE \\ Department of Chemical Engineering, University of Benin, Benin City, Edo State. Nigeria \\ *Corresponding Author Email: thelma.akhihiero@uniben.edu, Tel: 08063980390
}

\begin{abstract}
Effective storage conditions can resolve the challenge of food scarcity and extinction of certain food species. Therefore, this study investigated the changes in the food properties and mineral composition of tiger nuts at temperatures of $23,40,55,80$ and $100^{\circ} \mathrm{C}$. Results show that while the temperature of $55^{\circ} \mathrm{C}$ influenced water, crude protein and carbohydrate contents retention in the tiger nuts, fats were better retained at $80^{\circ} \mathrm{C}$. This indicates that food nutrients and properties of tiger nuts should be better retained at temperatures $\geq 50^{\circ} \mathrm{C}$.
\end{abstract}

\section{DOI: https://dx.doi.org/10.4314/jasem.v24i12.8}

Copyright: Copyright (C) 2020 Akhihiero et al. This is an open access article distributed under the Creative Commons Attribution License (CCL), which permits unrestricted use, distribution, and reproduction in any medium, provided the original work is properly cited.

Dates: Received: 22 October 2020; Revised: 28 November 2020; Accepted: 09 December 2020

Keywords: Food, Temperature, Properties, Composition

Tiger nut is a monocotyledonous plant with about 4000 species with high contents of starch, fat, sugar, protein, phosphorus, potassium and vitamins $\mathrm{E}$ and $\mathrm{C}$ (Ekeamyanwu and Ononogbu, 2010). Since it has high nutritional and low viscosity values, it is mostly cultivated for food and biodiesel production in the Valencia region of Spain, Australia, North and South America, Europe and Egypt (Adel et al, 2015). Though African countries are major producers and exporters of tiger nuts, it can however be grown in most regions of the world. This is because of its' good water retention capability, suitability to different soils and short maturity period (www. nwtf.org/conservation/bulletins/bulletin_07.pdf).

Moreover, current research is focused on food sources (Wells et al, 2017; Zhenzhang et al, 2019), extraction of food products (Chemat et al, 2017; Chen et al, 2019; Arya et al, 2019) and food processing techniques (Chemat et al, 2017; Barbosa-Canovas et al, 2019; Jones et al, 2019). However, food security should be given more attention due to the growing world population and consequences of neglect. To address this potential threat to human existence, researchers have investigated the effect of several factors on food supply. That is, few of the researched factors are the effect of pesticide residues (Carvalho 2017; Bonner and Alavanja 2017; Popp and Nagy 2012), and climatic conditions. Research has shown that temperature is a climatic factor that limits the maximum yield of crops (Davis et al, 2017).
For this reason, researchers have previously investigated the impact of temperature variation on wheat production (Parry et al, 2004). For example, Parry et al (2004) showed that temperature increase affected wheat production more than rainfall. Therefore, they concluded that crop yields dramatically decrease with increase in temperature. Though it has generally been accepted that temperature affects crop yields (Parry et al, 2004; Davis et al, 2017), more research is needed to examine the effect of temperature variation on other edible crops. This will determine the optimal temperature condition of storing fresh tiger nuts in order to preserve its' food and mineral components. As a result, this study is investigating the changes in the food properties and mineral composition of tiger nuts at different temperature conditions.

\section{MATERIALS AND METHODS}

Preparation and Analyses of fresh tiger nuts: Samples of fresh tiger nuts were purchased from a local market at Benin City, Edo State. Thereafter, they were washed with distilled water to remove impurities, without affecting their chemistry. Proximate composition analysis was conducted for the moisture content, crude protein content and carbohydrate contents of the tiger nuts. More so, the mineral and vitamin content analyses of tiger nuts samples were carried out. That is, the samples were analyzed for several minerals such as potassium, calcium, iron, copper and vitamins $\mathrm{C}$ and $\mathrm{E}$ contents. 
Calculation Procedures: The drying rate calculation for each samples at different temperatures were carried out using the formula:

$$
W=\frac{h A \Delta T}{\lambda} \ldots \ldots \ldots 1
$$

Where:

$$
\text { Area, } A=\frac{4}{D} \times \sqrt{1-a 2} \quad(\text { Kolev, 2011)........ } 2
$$

Diameter of tiger nut, $\mathrm{D}=6.27 \mathrm{~mm}$ (Sanchez et al, 2012): Heat transfer coefficient, $h=20.442$ (Perry chemical engineering handbook, 1999): Latent heat of vaporization of water $=22.6 \times 10^{5} \mathrm{~J} / \mathrm{Kg}($ Vaclavik and Christian, 2008).

\section{RESULTS AND DISCUSSION}

Table 1 presents the proximate composition of tiger nuts. Moisture content of the tiger nuts reduced with increasing temperature because of the effect of heat on vaporization of the moisture, present in the tiger nuts. However, the sharp increase at $55^{\circ} \mathrm{C}$ as well as the subsequent reduction could be due to the sudden exposure of the tiger nuts to atmospheric conditions, at the sun-drying temperature (Tunde and Oke, 2011). To illustrate, figure 2 shows a corresponding decrease in drying rate. This is as a result of the presence of atmospheric moisture. Furthermore, similar trends are reported for the crude protein, carbohydrate and fats contents. In brief, the temperature of $55^{\circ} \mathrm{C}$ influenced water, crude protein and carbohydrate contents retention in the tiger nuts, while fats were better retained at $80^{\circ} \mathrm{C}$. This is because, sun-drying at $55^{\circ} \mathrm{C}$ has shown to better preserve the food contents of tiger nuts in comparison to temperature at 40,80 , and $100^{\circ} \mathrm{C}$. Nevertheless, drying at $23^{\circ} \mathrm{C}$ is more preferable as it proves to retain more of the food contents. On the other hand, Table 2 shows the drying rates of the samples at different temperatures. It is presented that unlike the proximate composition, drying rate of tiger nuts increase with temperature. This indicates that higher temperature conditions better preserves the tiger nuts than lower temperatures.

\begin{tabular}{|c|c|c|c|c|c|}
\hline Components & $\begin{array}{l}\text { Sample A } \\
@ 23^{\circ} \mathrm{C}\end{array}$ & $\begin{array}{l}\text { Sample B } \\
\text { a } 5^{\circ} \mathrm{C}\end{array}$ & $\begin{array}{l}\text { Sample C } \\
\text { a } 40^{\circ} \mathrm{C}\end{array}$ & $\begin{array}{l}\text { Sample D } \\
\text { a } 80^{\circ} \mathrm{C}\end{array}$ & $\begin{array}{l}\text { Sample E } \\
\left(100^{\circ} \mathrm{C}\right.\end{array}$ \\
\hline Moisture Content (\%) & 20.60 & 12.50 & 5.40 & 4.52 & 3.62 \\
\hline Crude Protein (\%) & 2.70 & 2.20 & 1.16 & 1.60 & 1.35 \\
\hline Carbohydrate (\%) & 11.40 & 9.65 & 4.61 & 6.20 & 8.71 \\
\hline Fats and oils (\%) & 1.36 & 1.21 & 1.24 & 1.31 & 1.06 \\
\hline
\end{tabular}

Table 1: Proximate composition of tiger nuts

Table 2: Calculated drying rate of tiger nuts

\begin{tabular}{llllll}
\hline Samples & A & C & B & D & E \\
\hline Drying Reta & 1.5221 & 1.7567 & 1.7706 & 1.9905 & 2.1130 \\
\hline
\end{tabular}

Effect of drying on crude protein content: The results show the highest protein content of tiger nuts when it is freshly harvested at normal room temperature of $23^{\circ} \mathrm{C}$. Protein content decreased at temperatures of 55 , 40,80 and $100^{\circ} \mathrm{C}$. However, protein content was better retained at $55^{\circ} \mathrm{C}$, as shown in figure 1 . Research has similarly reported that protein content was best retained at $70^{\circ} \mathrm{C}$ (Hartati et al., 2018).

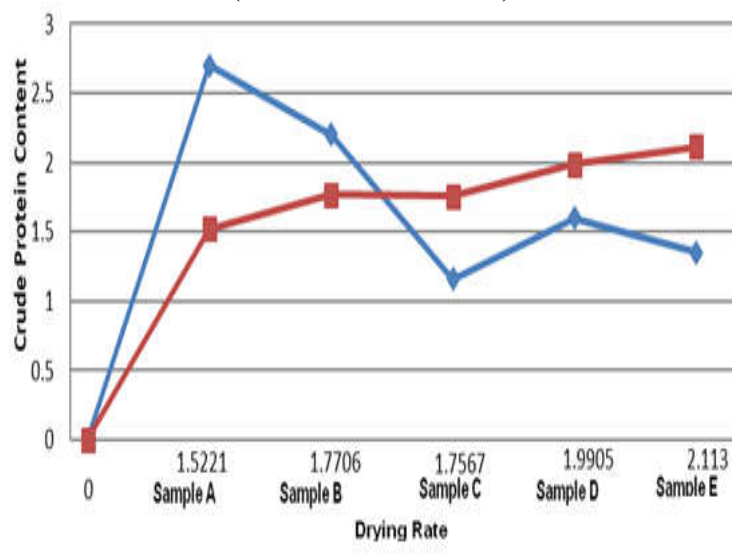

Figure 1: Effect of drying on crude protein content
Effect of drying on moisture content: Since drying at temperatures above $70^{\circ} \mathrm{C}$ increases the dissolved solids due to protein denaturation, the water content as shown in the effect of drying on moisture content in Figure 3 decreases. The water content was best retained at a temperature of $55^{\circ} \mathrm{C}$. This result agrees with that of Hartati et al, (2018) when they found that the water content of laksan sauce was best retained at a temperature of $60^{\circ} \mathrm{C}$.

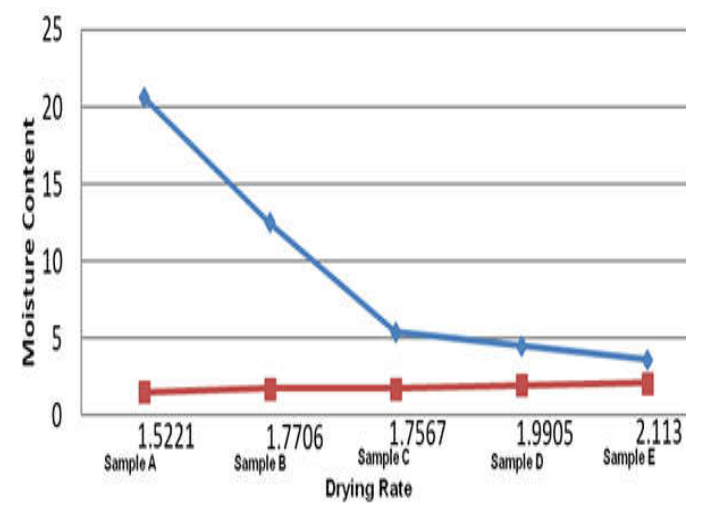

Figure 2: Effect of drying on moisture content 
Effect of drying on carbohydrate content: The results showed that the highest carbohydrate content was found in fresh tiger nuts at $23^{\circ} \mathrm{C}$. Negligible losses were observed in sample $\mathrm{B}$ with drying at $55^{\circ} \mathrm{C}$ and the lowest at $40^{\circ} \mathrm{C}$. It is shown that drying at $55^{\circ} \mathrm{C}$ best preserved the carbohydrate content with a negligible loss of $2.75 \mathrm{mg}$ relative to the fresh sample at $23^{\circ} \mathrm{C}$. A recent study conducted by Hartati et al, 2018 agrees with this finding. They showed from their results that the highest carbohydrate content was at $60^{\circ} \mathrm{C}$.

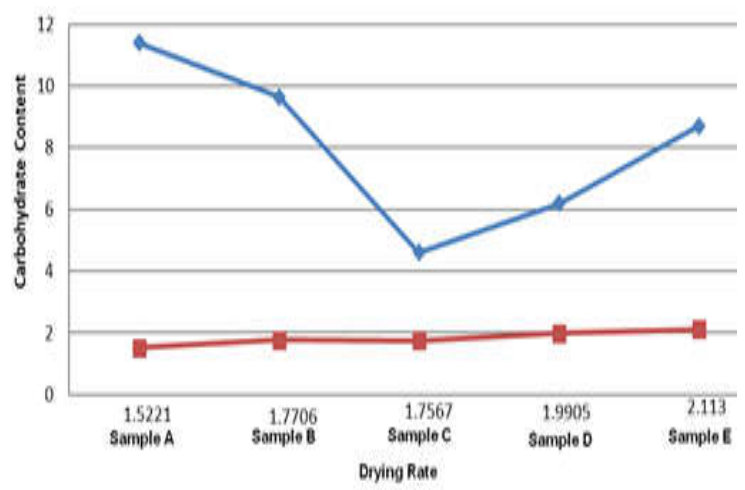

Fig 2: Effect of drying on carbohydrate content

Effect of drying rate on fats content: The results of this study showed that the highest fat content was at $23{ }^{\circ} \mathrm{C}$. However, when subjected to different temperature conditions, the fats contents were better retained at $80^{\circ} \mathrm{C}$ in comparison to other temperature conditions, as shown in figure 3 . When subjected to this temperature, only a negligible loss of $0.05 \mathrm{~g}$ was observed. Similarly, Hatati et al, (2018) obtained the maximum lipid content at $70^{\circ} \mathrm{C}$ in their experiment.

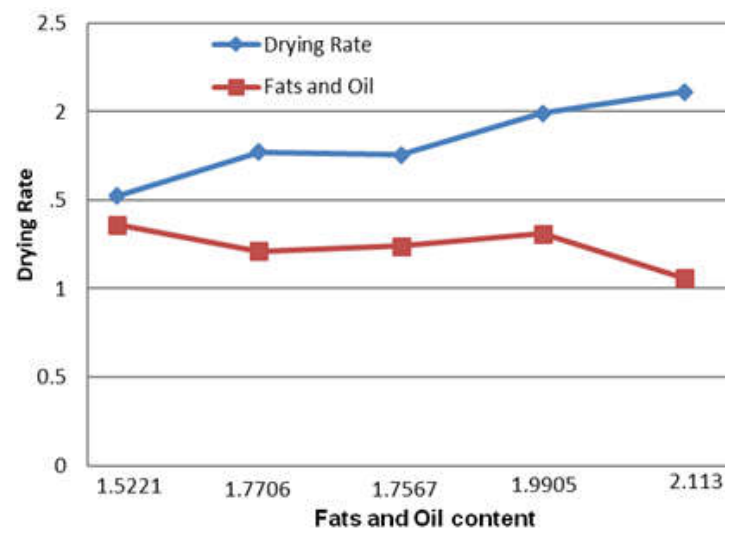

Figure 3: Effect of drying on fats and oil content

Mineral compositions of tiger nuts: The effect of a specific temperature of $23^{\circ} \mathrm{C}$ on the mineral composition of fresh tiger nuts is shown in Figure 4. It is shown that the properties of calcium, sodium and potassium are in significant amounts in freshly harvested tiger nuts when compared to presence of copper and iron.

Table 3: Mineral properties of tiger nuts

\begin{tabular}{|c|c|c|c|c|}
\hline \multirow{2}{*}{$\begin{array}{l}\text { Mineral } \\
\text { Components } \\
(\mathrm{mg} / \mathbf{1 0 0})\end{array}$} & \multirow[t]{2}{*}{$\begin{array}{l}\text { Sample A } \\
2^{0} \mathrm{C} \text { Fresh }\end{array}$} & \multirow{2}{*}{$\begin{array}{l}\text { Sample B @ } \\
55^{\circ} \mathrm{C} \text { *Sun- } \\
\text { dried }\end{array}$} & \multicolumn{2}{|c|}{$\begin{array}{l}\text { Ogunlade et al, } \\
2015\end{array}$} \\
\hline & & & Fresh & Dry \\
\hline $\mathrm{Na}$ & 22.73 & 19.27 & 101.30 & 101.17 \\
\hline K & 128.49 & 322.47 & 122.40 & 122.90 \\
\hline $\mathrm{Ca}$ & 20.05 & 31.46 & 83.00 & 91.60 \\
\hline $\mathrm{Fe}$ & 1.72 & 3.39 & 3.60 & 3.80 \\
\hline $\mathrm{Cu}$ & 0.21 & 0.59 & 0.20 & 0.30 \\
\hline
\end{tabular}

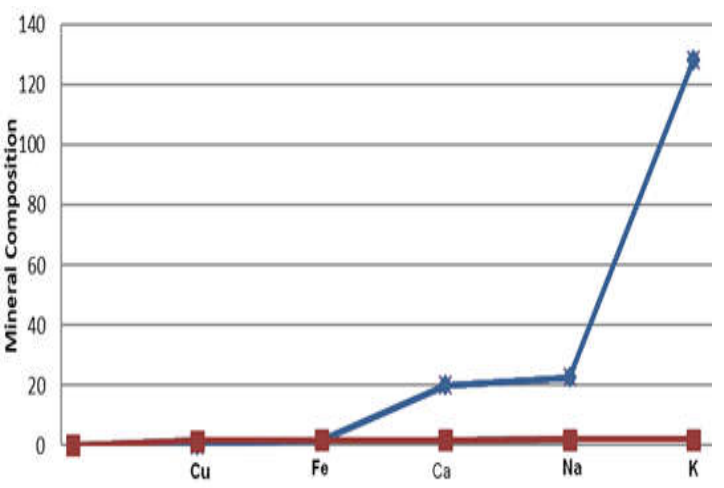

Fig 4: mineral properties of tiger nuts at $23^{\circ} \mathrm{C}$

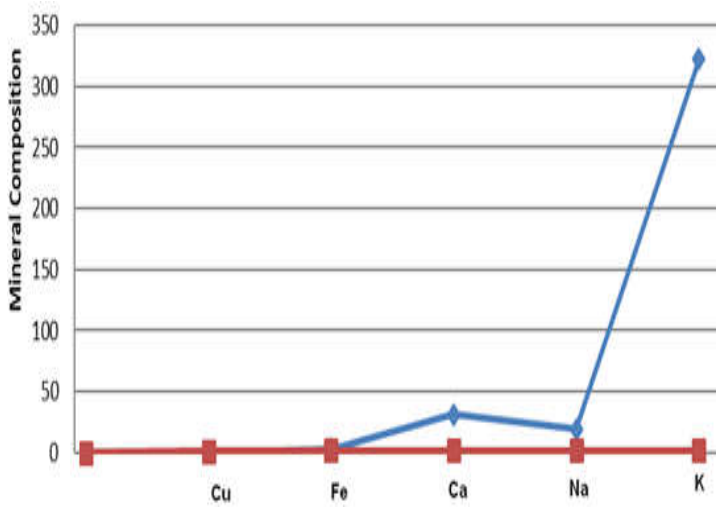

Fig 5: mineral properties of tiger nuts at $55^{\circ} \mathrm{C}$

The mineral composition of tiger nuts dried at $55^{\circ} \mathrm{C}$ is shown in Figure 5. Even with an increase in temperature from $23^{\circ} \mathrm{C}$ to $55^{\circ} \mathrm{C}$, calcium, sodium and potassium are still the major constituents of tiger nuts though the amount of sodium present has reduced. From the effect of temperature increase $\left(23-55^{\circ} \mathrm{C}\right)$ on the mineral compositions of tiger nuts, the examined food minerals $(\mathrm{Cu}, \mathrm{Fe}, \mathrm{K}, \mathrm{Ca})$ increased by $0.38 \mathrm{mg}$, $1.67 \mathrm{mg}, 193.98 \mathrm{mg}$, and $11.41 \mathrm{mg}$ respectively, while sodium decreased by $3.46 \mathrm{mg}$. Therefore, increase in temperature enhances the mineral composition of most properties of tiger nuts.

Conclusion: The results of this study showed that temperature had a significant effect on the food 
properties and mineral composition of tiger nuts. Drying at $55^{\circ} \mathrm{C}$ produced the best results for the properties of crude protein, moisture content and carbohydrate, in comparison to 40,80 and $100^{\circ} \mathrm{C}$. However, heating at $80^{\circ} \mathrm{C}$ was best for maximum fats and oil retention. Storage at the right condition will prevent the challenge of food scarcity and loss of essential nutrients.

\section{REFERENCES}

Adel AAM, Awad AM, Mohamed HH, Iryna S. (2015). Chemical composition, physicochemical properties and fatty acid profile of Tiger nut (Cyperus esculentus L.) seed oil as affected by different preparation methods. Int Food Res J, 22(5): 1931-8

Arya SS, Kaimal AM, Chib M, Sonawane SK, Show PL. (2019). Novel, energy efficient and green cloud point extraction: technology and applications in food processing. J. Food Sci Tech, 56(2); 524-34.

Barbosa-Canovas GV; Zhang H. (2019). Pulsed electric fields in food processing: Fundamental aspects and applications. CRC Press.

Bonner MR; Alavanja MCR. (2017). Pesticides, human health and food security. Food Ener Sec. 6(3): 89-93.

Brenneman R; Daniel H. Turkey Gold. http://www.nwtf.org/conservation/bulletins/bulle tin 07.pdf

$\begin{array}{llll}\text { Burden } & \text { D. (2012). Chufa. }\end{array}$ http:/www.agmrc.org/commodities products/gr ains_oilseeds/chufa/

Carvalho FP (2017). Pesticides, environment and food safety. Food Ener Sec. 6(2): 48-60.

Chemat F, Rombaut N, Meullemiestre A, Turk M, Perino S, Fabiano-Tixier A-S, Abert-Vian M. (2017). Review of green food processing techniques: Preservation, transformation, and Extraction. Innovative Food Sci Emer techn, 41; 357-77.

Chemat F, Rombaut N, Sicaire A-G, Meullemiestre A, Fabiano-Tixier A-S, Abert-Vian M. (2017). Ultrasound- assisted extraction of food and natural products. Mechanisms, techniques, combinations, protocols and applications: A review. Ultra Sonochem, 34; 540-60.
Chen J, J, Ying G-G, Deng W-J. (2019). Antibiotic residues in food: Extraction, Analysis, and Human Health Concerns. J. Agric Food Chem, 67; 7569-86.

Davis KF, Rulli MC, Seveso A, D’Odorico P. (2017). Increased food production and reduced water use through optimized crop distribution. Nat Geosci. DOI: $10.1038 / \mathrm{s} 41561-017-0004-5$

Ekeamyanwu RC; Ononogbu CI (2010). Nutritive value of Nigerian tiger nut (Cyperus esculentus L.). Agric J, 5; 297-302.

Hartati Y, Priyanto G, Yuliati K, Pambayun R. (2018). Effect of temperature and drying time on chemical and proximate characteristics of Laksan Sauce as a Palembang Traditional Food. Pak J Nut, 17: 64-70.

Jones JM. (2019). Food processing: Criteria for dietary guidance and public health. Proceedings of the Nutrition Society. Cambridge University Press, 78(1), 4-18

Kolev NI. (2011). Heat and Mass transfer at the film/gas interface. In: Multiphase flow dynamics 3. 13. 319-57.

Popp J, Peto K, Nagy J. (2013). Pesticide productivity and food security. A review. Agron. Sustain. Dev. 33:243-55.

Perry RN; Green DW (1999). Perry's chemical engineers' handbook $7^{\text {th }}$ Edition. McGraw-Hill Companies, Inc.

Pereira LS (2017). Water, Agriculture and Food: Challenges and Issues. Wat Res Man. DOI: 10.1007/s1 1269-017-1664-z

Tunde-Akintunde TY; Oke MO (2011). Thin-layer drying characteristics of tiger nut (Cyperus esculentus) seeds. J Food Proc Pres. DOI: 10.1111/j.1745-4549.2011.00604.x

Vaclavik VA; Christian EW (2008). Water. Essentials of Food Science. In: Food Science Texts Series.. 2. 21-31.

Wells ML, Potin P, Craigie JS, Raven JA, Merchant SS, Helliwell KE, Smith AG, Camire ME, Brawley SH. (2017). Algae as nutritional and functional food sources: revisiting our understanding. J Appl Phy, 29; 949-82. 